\title{
Metal and Metal Oxide Based Advanced Ceramics for Electrochemical Biosensors-A Short Review
}

\author{
G. Bala Subbaiah ${ }^{1}$, K. Venkata Ratnam ${ }^{1}$, S. Janardhan ${ }^{1}$, K. Shiprath ${ }^{1}$, H. Manjunatha ${ }^{1 *}$, \\ M. Ramesha ${ }^{2}$, N. V. Krishna Prasad ${ }^{3}$, S. Ramesh ${ }^{3}$ and T. Anil Babu ${ }^{3}$
}

${ }^{1}$ Department of Chemistry, GITAM School of Science, GITAM University, Bengaluru, India, ${ }^{2}$ Department of EECE, School of Technology, GITAM University, Bengaluru, India, ${ }^{3}$ Department of Physics, GITAM School of Science, GITAM University, Bengaluru, India

\section{OPEN ACCESS}

Edited by:

Ravinder Dachepalli,

Osmania University, India

Reviewed by:

Asghari Maqsood

Air University, Pakistan

Rajender Boddula,

National Center for Nanoscience and

Technology (CAS), China

Padma Suvarna,

Jawaharlal Nehru Technological

University Anantapur, India

*Correspondence:

H. Manjunatha

hanumanjunath80@gmail.com

Specialty section:

This article was submitted to

Ceramics and Glass,

a section of the journal

Frontiers in Materials

Received: 17 March 2021

Accepted: 14 May 2021

Published: 02 June 2021

Citation:

Subbaiah GB, Ratnam KV,

Janardhan S, Shiprath $K$,

Manjunatha H, Ramesha M,

Prasad NVK, Ramesh S and Babu TA

(2021) Metal and Metal Oxide Based

Advanced Ceramics for

Electrochemical Biosensors-A

Short Review.

Front. Mater. 8:682025.

doi: $10.3389 /$ fmats.2021.682025
Identifying and quantifying the biological concentrations of certain biomolecules such as dopamine, glucose, tyrosine, and cholesterol, etc. has become the basis for medical diagnosis in the treatment of a number of related diseases. In most cases, the concentrations of these biomolecules in biofluids like blood acts as a biomarker and becomes crucial in the treatment of diseases. On the other hand, advanced ceramics refers to oxides (alumina, zirconia), non-oxides: (carbides, borides, nitrides, silicides), Composites (particulate reinforced combinations of oxides and non-oxides), etc. This review article discusses recent developments in the field of electrochemical sensors developed using metal and metal oxide based advanced ceramics with an emphasis on developments in the field over the past five years. The article presents the key results, important findings, and interesting chemistry of biosensing advanced ceramic based electrochemical biosensors for some important biomolecules such as acetaminophen, glucose, and dopamine, etc.

Keywords: advanced ceramics, electrochemical biosensors, cyclic voltammetry, chronoamperometry, biomolecules such as dopamine, glucose, acetaminophen

\section{INTRODUCTION}

The development of electrochemical sensors for chemical and biological sensing has made remarkable advantages in recent years with various applications (Worsfold, 1995). The electrochemical detection mechanism has played a vital role in medical applications such as disease diagnosis. Due to the highly sensitive and selective nature of electrochemical sensors, the real-time analysis of various analytes is possible with the help of portable and simple operated design equipment (Veloso et al., 2012).

Sensors detect a given input signal and convert it into different combinations of output readings. These sensors are typically operated with specified analytes and certain sample types with other environmental conditions (Worsfold, 1995) Electrochemical sensors have been widely used in various applications, for example in the quality control of industrial products, human health activity monitoring, predicting emissions, medical diagnostics, home safety alarms, and many other applications. The design of electrochemical sensors is based on the parametric nature of sensor devices. Typically, the parameters are electronic, either current, voltage, or reactance change affected 


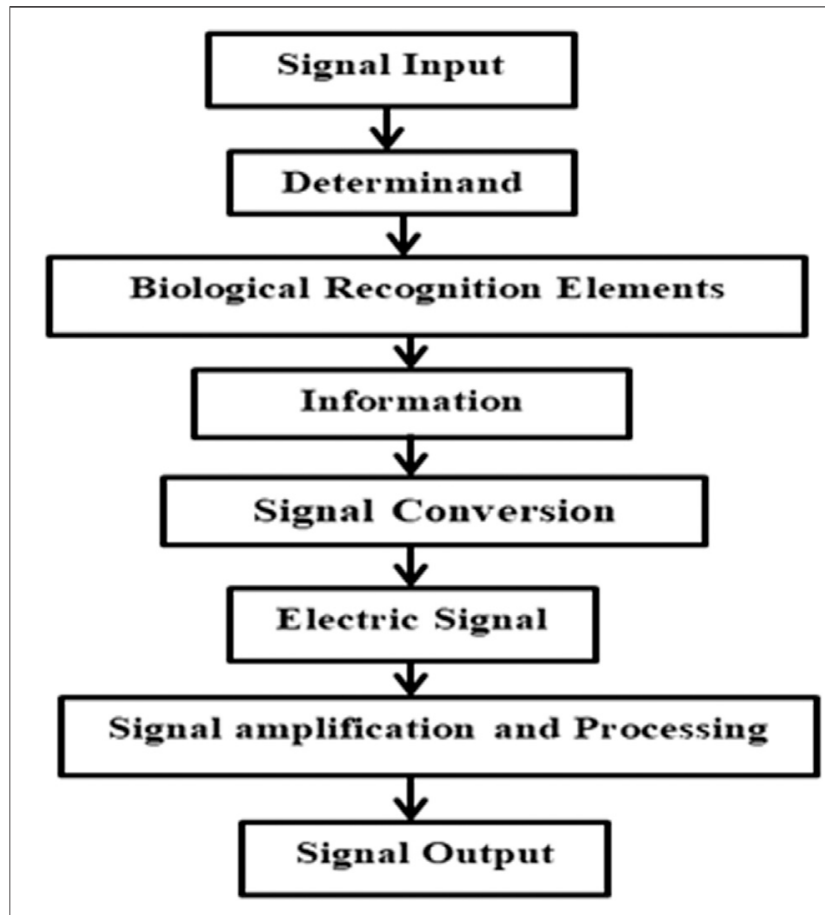

FIGURE 1 | Schematic of sensing by biosensors.

by varying analyte configuration. Electrochemical sensors can be extensively used for any form of solid, liquid, and gaseous analytes. The information captured from electrochemical sensors which are generally due to an interaction between analyte and electrode elements is converted into a qualitative or quantitative electrical signal (Vinay et al., 2020).

Electrochemical biosensors also play a vital role in many applications such as in medical diagnostics, monitoring environmental gases, and improving oxygen levels. They are also extensively used to monitor bioactivity in various compounds and organic materials. The working principle of bio-sensors is based on the use of a biomolecule to detect the concentration of a target bio-molecule. Biosensors are generally considered a subcategory of chemical sensors due to the transduction methods they employ (Joseph et al., 2003). A combination of electrochemical transducers, an electrode is attached, and a biomolecule is identified by the electrochemical biosensors. The dual nature of electrochemical biosensors can be used for applications such as real-time monitoring of the environment or subjects or targets in the form of selectivity and sensitivity. The major advantages of electrochemical biosensors over traditional analytical methods are that these materials could lead to various new features in chemical and biomedical applications in the future (Ruano, 2016). In General, biosensors are devices which convert a biological event or reaction into a readable output signal for analysis purpose (Hernandez-Vargas et al., 2018).

The biosensor's basic principle can be described as follows; it is sensitive to nucleic acids, cells, antibodies, enzymes, and other biological activities. The working principle is based on acquiring the target reaction between base elements and exhibiting sensitivity through a physical or chemical transducer. The range of reactive conditions acquired by the discrete or continuous nature of the signals is the basic information for the biosensor device's analysis purpose. Electrochemical biosensors are composed of sensitive filament and electrochemical signal converter. The sensitive film is mainly used to identify the analytes and the electrochemical signal converter is to convert biomass activity to electrical signals. The basic working principle of biosensors is described in Figure 1.

The electrochemical biosensors are classified based on the nature of the transducer into potentiometric, amperometric, and impedimetric transducers. These individual transducers convert the chemical information into measurable resistive, amperometric, and reactive signals, respectively. Electrochemical biosensors have been used in extensive ways, with various applications, for over fifty years. Generally, the materials used for electrochemical sensors are categorized into the electrode and supporting substrates for electroanalytical performances and the recognition of the biological elements. Figure 2 shows the scheme of an electrochemical biosensor. Here biological sensing elements are coupled to the electrodes. Transducers used in the electrode elements convert the electric signal into a readable output to the processing circuit for monitoring purposes (Hernandez-Vargas et al., 2018). The advancement and adaptation of electrochemical biosensors seem to possess great potential for the future. The technological gains in electrochemical biosensors with a range of practical uses, through a combination of selective biochemical detection methods, have led to a new era in the field of chemistry (Pohanka and Skladal, 2008).

\section{ADVANCED CERAMICS}

The design strategies that have driven biosensor development include detecting and measuring the parameters, transducer working mechanism, the technology, materials used for sensor fabrication, and finally, applications (Hernandez-Vargas et al., 2018). Various materials have been explored in recent years for their electrochemical sensing and biosensing applications in various fields. Advanced ceramic materials are one such material used for the fabrication of electrochemical and biosensors. Researchers have emphasized the utilization of advanced ceramic materials for selecting, sensing, and detecting certain materials. These are summarized in Table 1 below.

Advanced ceramics are becoming a more attractive option in modern technological applications with maximum focus on material properties. This focus on material properties has led to a significant expansion in research and development, and in optimizing the properties of ceramics and their matrix composites. Traditionally ceramics either inorganic or nonmetallic solids are prepared from powdered materials by applying heat and possess characteristic properties, including hardness, strength, low electrical conductivity, and brittleness. 


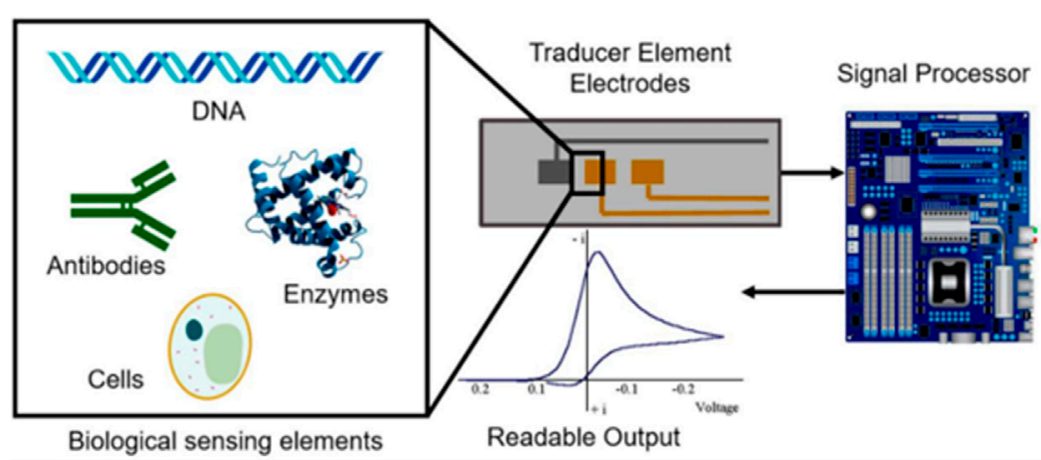

FIGURE 2 | Scheme of an electrochemical biosensor.

TABLE 1 | Examples of advanced ceramic materials and their various applications.

\begin{tabular}{lll}
\hline SI.No & \multicolumn{1}{c}{ Ceramic materials } & \multicolumn{1}{c}{ Applications } \\
\hline 1 & Alumina & Identification of environmental gas \\
2 & Pyro electric & Vapors identification \\
3 & Alpha sense oxidative gas & $\mathrm{NO}_{2}$ and $\mathrm{O}_{3}$ Concentration identification
\end{tabular}

Advanced ceramics represent a modern class of materials which are generally new materials or a combination of traditional ceramic materials designed to exhibit surprising variations in the properties traditionally ascribed to ceramics. As a result of these modern synthetic approaches to advanced ceramics, we now have new ceramic products that are as tough and electrically conductive as some metals. This is a very important characteristic property for any material used in electrochemical biosensors. Developments in advanced ceramics continue at a rapid pace constituting what can be considered a revolution in the kind of materials and properties obtained.

In 1993, the Versailles Project on Advanced Materials and Standards (VAMAS), described advanced ceramics as "an inorganic, non-metallic (ceramic), basically crystalline material of rigorously controlled composition and manufactured with detailed regulation from highly refined and/or characterized raw materials giving precisely specified attributes." The distinguishing features of advanced ceramics from the above definition is that they lack a glassy component, i.e., they are "basically crystalline." and their microstructures such as grain sizes, grain shapes, porosity, and phase distributions are carefully planned, engineered and controlled. This planning requires detailed monitoring of composition and processing with "clean-room" processing being the norm. Pure synthetic compounds, rather than naturally occurring raw materials, are used as precursors in manufacturing. As a result of these manufacturing conditions, the final advanced ceramics tend to exhibit unique or superior functional attributes. Examples include unique electrical properties such as superconductivity or superior mechanical properties such as enhanced toughness or high-temperature strength.

\section{ALUMINUM OXIDE BASED BIOSENSORS}

The search for metal oxides that can be used in electrochemical sensors to detect various analytes has recently started to focus on aluminum oxide, which has become a prominent candidate. $\mathrm{Al}_{2} \mathrm{O}_{3}$ has been widely used as a good gate dielectric for the future of nano electronic devices due to its high dielectric constant, remarkable hardness, thermal stability, uniform pore size, and high pore density together with the potential low cost and relatively simple preparation procedure. Among different phases of $\mathrm{Al}_{2} \mathrm{O}_{3}$ viz. $\gamma, \eta, \delta, \theta$, and $\chi$ phases, the $\alpha-\mathrm{Al}_{2} \mathrm{O}_{3}$ possess thermodynamic stability. Each form of the $\mathrm{Al}_{2} \mathrm{O}_{3}$ has its specific band gap value, particularly, $\alpha, \beta$, and $\gamma \mathrm{Al}_{2} \mathrm{O}_{3}$ phases have $8.8 \mathrm{eV}$, 7.0-8.7 eV, and 5.1-7.1 eV, respectively. $\mathrm{Al}_{2} \mathrm{O}_{3} \mathrm{NPs}$ have been prepared by various methods like laser ablation, sol-gel, hydrothermal reactions, pyrolysis, sputtering, and pyrolysis, etc.

During the past few years, $\mathrm{Al}_{2} \mathrm{O}_{3}$ NPs have been synthesized and there has been increasing attention on applications in several fields such as photocatalysts, sensors, capacitors, and semiconductors. An electrochemical biosensor was fabricated (Mekawy et al., 2018) for the detection of NADH using a nanocomposite of alumina with GO. In another work, PANI with $\gamma-\mathrm{Al}_{2} \mathrm{O}_{3}$ nanocomposite was synthesized (Parvin et al., 2018) via in situ electro polymerization method on gold electrodes for detection of vitamin-E which exhibited good lowest detection limit (LOD) of $0.06 \mu \mathrm{M}$. A ternary $\mathrm{ZnO} / \mathrm{NiO} /$ $\mathrm{Al}_{2} \mathrm{O}_{3}$ nanoparticles were prepared by Alam et al. (2020) for the detection of L-Glutamic acid using a glassy carbon electrode as a non-enzymatic electrode. Sivasankar et al. (2018) introduced a new hierarchical mesoporous graphite oxide (HMGO) with $\mathrm{Al}_{2} \mathrm{O}_{3}$ for the identification of caffeic acid in red wine samples using a modified GCE. For the detection of glycine, Alam et al. 
TABLE 2 | $\mathrm{Al}_{2} \mathrm{O}_{3}$ nanoparticles as ceramic sensors for detection of biomolecules.

\begin{tabular}{|c|c|c|c|c|c|}
\hline SI. No & Nanomaterial/Composite & Analyte & LOD & Sensitivity & References \\
\hline 1 & $\mathrm{Al}_{2} \mathrm{O}_{3}-\mathrm{GO}$ & $\mathrm{NADH}$ & $4.5 \mu \mathrm{M}$ & - & Mekawy et al. (2018) \\
\hline 2 & PANI with $\gamma-\mathrm{Al}_{2} \mathrm{O}_{3}$ & Vitamin E & $0.06 \mu \mathrm{M}$ & - & Parvin et al. (2018) \\
\hline 3 & Ternary $\mathrm{ZnO} / \mathrm{NiO} / \mathrm{Al}_{2} \mathrm{O}_{3}$ & L-Glutamic acid & $95.35 \mathrm{pM}$ & - & Alam et al. (2020) \\
\hline 4 & Hierarchical mesoporous graphite oxide/ $\mathrm{Al}_{2} \mathrm{O}_{3}$ & Caffeic acid & $0.004 \mu \mathrm{M}$ & $429 \mu \mathrm{A} \mathrm{mM}{ }^{-1} \mathrm{~cm}^{-2}$ & Sivasankar et al. (2018) \\
\hline 5 & $\mathrm{ZnO} / \mathrm{Al}_{2} \mathrm{O}_{3} / \mathrm{Cr}_{2} \mathrm{O}_{3}$ & Glycine & $82.25 \mathrm{pM}$ & $\begin{array}{c}2.09 \times 10^{2} \\
-\end{array}$ & Alam et al. (2018a) \\
\hline 6 & TPhPFe(III)/ $/ \mathrm{Al}_{2} \mathrm{O}_{3} / \mathrm{Pb}$ and TPhPFe(III)/ $\mathrm{Al}_{2} \mathrm{O}_{3} / \mathrm{Si}$ & $\mathrm{H}_{2} \mathrm{O}_{2}$ & - & - & Malikova et al. (2015) \\
\hline 7 & Pt- $\gamma-\mathrm{Al}_{2} \mathrm{O}_{3}$ composite & Guaiacol & $17.9 \mathrm{nM}$ & - & Sun et al. (2015a) \\
\hline 8 & $\mathrm{Cu}-\mathrm{Al}_{2} \mathrm{O}_{3}-\mathrm{g}-\mathrm{C}_{3} \mathrm{~N}_{4}-\mathrm{Pd}$ & Amyloid $\beta$-Protein & $3.3 \mathrm{fg} \mathrm{ml}^{-1}$ & - & Miao et al. (2019) \\
\hline 9 & Graphite- $\mathrm{SiO}_{2} / \mathrm{Al}_{2} \mathrm{O}_{3} / \mathrm{Nb}_{2} \mathrm{O}_{5}$-methylene blue & Dopamine & $1.49 \mu \mathrm{mol} \mathrm{L}^{-1}$ & - & Giarola et al., 2017 \\
\hline 10 & $\mathrm{ZnO} / \mathrm{Al}_{2} \mathrm{O}_{3}$ Nanocomposite & Dopamine & $2.0 \times 10^{-6} \mathrm{M}$ & - & Ganjali et al. (2018) \\
\hline 11 & $\mathrm{ZnO} / \mathrm{Al}_{2} \mathrm{O}_{3}$ nanocomposite & Salicylic acid & $0.25 \mu \mathrm{M}$ & - & Ganjali et al. (2017a) \\
\hline 12 & $\mathrm{ZnO} / \mathrm{Al}_{2} \mathrm{O}_{3}$ nanocomposite & Ascorbic acid & $0.6 \mu \mathrm{M}$ & - & Ganjali et al. (2017b) \\
\hline 13 & MWNTs $/ \mathrm{Al}_{2} \mathrm{O}_{3} /$ chitosan & Serotonin & $0.005 \mu \mathrm{M}$ & - & Wu et al. (2018) \\
\hline 14 & MWNTs $/ \mathrm{Al}_{2} \mathrm{O}_{3} /$ Poly-L-Lysine Composite & Salicylic acid & $0.25 \mu \mathrm{M}$ & - & Wang et al. (2018) \\
\hline 15 & $\mathrm{ZnO} / \mathrm{Al}_{2} \mathrm{O}_{3} / \mathrm{Cr}_{2} \mathrm{O}_{3}$ & Xanthine & $1.34 \mathrm{pM}$ & $70.8861 \mathrm{~mA} \mu \mathrm{M}^{-1} \mathrm{~cm}^{-2}$ & Alam et al. (2018b) \\
\hline 16 & $\mathrm{TiO}_{2}-\mathrm{Al}_{2} \mathrm{O}_{3}$ Nanocomposite & 3,4-diaminotoluene & $0.19 \mathrm{pM}$ & $0.5024 \times 10^{3} \mu \mathrm{A} \mu \mathrm{M}^{-1} \mathrm{~cm}^{-2}$ & Rakib et al. (2019) \\
\hline
\end{tabular}

(2018a) developed a non-enzymatic electrochemical sensor of modified GCE using low dimensional ternary $\mathrm{ZnO} / \mathrm{Al}_{2} \mathrm{O}_{3} / \mathrm{Cr}_{2} \mathrm{O}_{3}$ nanoparticles, where it exhibited a good limit of detection of 82.25 pM. Interestingly Malikova et al. (2015) developed a biomimetic electrode using catalase on TPhPFe(III) $/ \mathrm{Al}_{2} \mathrm{O}_{3} / \mathrm{Pb}$ and $\mathrm{TPhPFe}(\mathrm{III}) / \mathrm{Al}_{2} \mathrm{O}_{3} / \mathrm{Si}$ for the detection of low amounts of $\mathrm{H}_{2} \mathrm{O}_{2}$.

To find out a polyphenol analyte of guaiacol in food samples, the research group of Sun et al. (2015a developed an electrochemical sensor using $\mathrm{Pt}-\gamma-\mathrm{Al}_{2} \mathrm{O}_{3}$ modified GCE that exhibits good results. An electrochemical immunosensor was developed by Miao et al. (2019) taking $\mathrm{Cu}$ doped $\mathrm{Al}_{2} \mathrm{O}_{3}$ with graphite carbon nitride $\left(\mathrm{g}-\mathrm{C}_{3} \mathrm{~N}_{4}\right)$ to generate $\mathrm{CueAl}_{2} \mathrm{O}_{3}-\mathrm{g}-\mathrm{C}_{3} \mathrm{~N}_{4}$ for the detection of amyloid $\beta$-protein (A $\beta$ ). Giarola et al. (2017) identified that graphite- $\mathrm{SiO}_{2} / \mathrm{Al}_{2} \mathrm{O}_{3} / \mathrm{Nb}_{2} \mathrm{O}_{5}$-methylene blue (GRPSiAlNb-MB) composite was suitable for the detection of dopamine, $\mathrm{DA}$, in real and pharmaceutical samples with good detection limit. Other works by (Ganjali et al., 2017a; Ganjali et al., 2017b; Ganjali et al., 2018) have also reported the detection of DA by modifying a glassy carbon electrode (GCE) using $\mathrm{ZnO} / \mathrm{Al}_{2} \mathrm{O}_{3}$ nanocomposite. The same group of workers suggested that $\mathrm{ZnO} / \mathrm{Al}_{2} \mathrm{O}_{3}$ nanocomposite can also be used for the determination of salicylic acid and ascorbic acid in pharmaceutical samples. In another study by Zheng et al. (2018) brain serotonin 5-hydroxy tryptamine was detected using a modified screen-printed electrode (SPE) based on MWCNTs/ $\mathrm{Al}_{2} \mathrm{O}_{3} /$ Chitson composite. In addition to the above electrochemical studies, Wang et al. (2018) developed a novel disposable sensor modified with $\mathrm{MWNTs} / \mathrm{Al}_{2} \mathrm{O}_{3} /$ poly-llysine film for the detection of clinical $17 \beta$-estradiol (17 $\beta$-E2) urine samples. Alam et al. (2018b) have studied a chemical sensor based on $\mathrm{ZnO} / \mathrm{Al}_{2} \mathrm{O}_{3} / \mathrm{Cr}_{2} \mathrm{O}_{3}$ nanocomposite, which is used for modification of GCE for sensing xanthine with good sensitivity and limit of detection. $\mathrm{A} \mathrm{TiO}_{2}-\mathrm{Al}_{2} \mathrm{O}_{3}$ nanocomposite was synthesized by Rakib et al. (2019) and was used for the modification of GCE as a chemical sensor for sensing hazardous chemical 3,4-diaminotoluene. It is clearly understood from the above findings and developments that the dominant properties of alumina particles can be unraveled in the form of nanocomposite with various other metal oxides, metals, polymers, and carbon materials like graphene, graphene oxide. Table 2 provides a summary of the electrochemical biosensor properties of $\mathrm{Al}_{2} \mathrm{O}_{3}$ based sensors for the detection of various biomolecules.

\section{ZIRCONIUM OXIDE BASED BIOSENSORS}

The $\mathrm{ZrO}_{2}$ exists in various structures including monoclinic, tetragonal, cubic lattice imbibe with unique thermal, structural, electronic properties. It has a fine natural color, high stability, high toughness, high chemical strength, desirable resistance to corrosion, chemical, and microbial action that have made it a highly significant advanced ceramic in terms of its technological aspects (Sagadevan et al., 2016).

For the past 2 decades, a large amount of attention has been focused on zirconium oxide nanoparticles due to their particle sizedependent properties. Outstanding properties like a high surface area to volume ratio, surface activity, catalytic efficiency, strong adsorption affinity, biocompatibility, facile electron transfer rate, and chemical inertness make the nanostructured zirconium oxide particles an interesting material in the field of electrochemical sensors. This has led to many researchers exploring its applications. It also offers a great affinity for proteins like enzymes, which lead to immobilization of enzyme activity, the finest feature of bio-sensing applications as well as non-toxicity, low thermal conductivity, and high isoelectric point. Due to the availability of plenty of oxygen vacancies on its surface and a wide band gap for that p-type semiconductor, it is also used as an insulator in transistors and as a dielectric material. The high ion exchangeability and redox movement make it useful in many catalytic processes as a catalyst. Different approaches have been used to synthesize the ultrafine ceramic powders of $\mathrm{ZrO}_{2}$, such as sol-gel, hydrothermal, spray pyrolysis, salt-assisted aerosol decompositions, carbon nanotube templated technique, and reflux and emulsion precipitation, etc. 
TABLE 3 | Properties of metal carbide and nitride materials through carbothermic reduction approach.

\begin{tabular}{|c|c|c|c|c|c|}
\hline Precursor & Product & Shape & Particle size & $\begin{array}{l}\text { Surface area } \\
\qquad\left(\mathrm{m}^{2} / \mathrm{g}\right)\end{array}$ & Reference \\
\hline $\begin{array}{l}\mathrm{Fe}_{2}\left(\mathrm{C}_{2} \mathrm{O}_{4}\right)_{3} \\
\mathrm{Fe}\left(\mathrm{C}_{6} \mathrm{H}_{5} \mathrm{O}_{7}\right) \\
\left.\mathrm{Fe}\left(\mathrm{C}_{2} \mathrm{H}_{3} \mathrm{O}_{2}\right)_{2}\right)\end{array}$ & $\mathrm{C}-\mathrm{Fe}$ & Sphere & $20-50 \mathrm{~nm}$ & 38-95 & Hoch et al. (2008) \\
\hline $\mathrm{F}_{3} \mathrm{O}_{4}$ & $\mathrm{Fe}_{3} \mathrm{C}$ & Sphere & $20 \mathrm{~nm}$ & - & Schnepp et al. (2010) \\
\hline $\mathrm{Fe}(\mathrm{CO})_{5}$ & $\mathrm{Fe}-\mathrm{Fe}_{3} \mathrm{C}$ & Core-shell & $30-50 \mathrm{~nm}$ & - & Wang et al. (2007) \\
\hline Ferrocene & $\mathrm{Fe}_{3} \mathrm{C}$ & - & $18-23 \mathrm{~nm}$ & - & Huo et al. (2006) \\
\hline Ferrocene & $\mathrm{Fe}_{3} \mathrm{C}$ & Sphere & $50-100 \mathrm{~nm}$ & $15-39.8$ & Sajitha et al. (2007) \\
\hline $\mathrm{SiO}_{2}$ & $\mathrm{SiC}$ & Sphere & - & - & Weimer et al. (1993) \\
\hline $\mathrm{TiCl}_{4}$ & $\mathrm{TiC}$ & Whiskers & $150 \mu \mathrm{m}$ & - & Kim and Kumta (2003) \\
\hline $\mathrm{TiCl}_{4}, \mathrm{ZrCl}_{4}$ & TiN, ZrN & Whiskers & - & - & Kato et al. (1980) \\
\hline $\mathrm{TiO}_{2}$ & $\mathrm{TiC}$ & Whiskers & $1-10 \mu \mathrm{m}$ & & Wokulski (1987) \\
\hline $\mathrm{TiO}_{2}$ & $\mathrm{TiC}$ & Whiskers & - & - & Krishnarao et al. (2001) \\
\hline $\mathrm{Nb}_{2} \mathrm{O}_{5}$ & $\mathrm{NbC}$ & Whiskers & $0.1-0.5 \mu \mathrm{m}$ & - & Johnsson (2000) \\
\hline $\mathrm{TiCl}_{4}$ & $\mathrm{TiN}$ & Whiskers & $30 \mu \mathrm{m}$ & - & Bojarski et al. (1981) \\
\hline $\mathrm{Ta}_{2} \mathrm{O}_{5}$ & $\mathrm{TaC}$ & Whiskers & $0.5-1 \mu \mathrm{m}$ & - & Johnsson (2004) \\
\hline $\mathrm{TiO}_{2}$ & $\mathrm{TiC}$ & Nanowire & $20-50 \mu \mathrm{m}$ & - & Huo et al. (2007) \\
\hline
\end{tabular}

TABLE 4 | Metal carbide, Metal Nitride based electrochemical sensors for detection of various species.

\begin{tabular}{|c|c|c|c|c|c|}
\hline Electrode & Analyte & Detection method & Detection limit & Detection range & Reference \\
\hline $\mathrm{Hb} / \mathrm{Ti}_{3} \mathrm{C}_{2}-\mathrm{GO} /$ gold foil electrode & $\mathrm{H}_{2} \mathrm{O}_{2}$ & Amperometry & $1.95 \mu \mathrm{M}$ & $2 \mu \mathrm{M}-1 \mathrm{mM}$ & Zheng et al. (2018) \\
\hline $\mathrm{LO} / \mathrm{CNTs} / \mathrm{Ti}_{3} \mathrm{C}_{2} \mathrm{Tx} / \mathrm{Pb} / \mathrm{CFMs}$ & Lactase & Chronoamperometry & $0.67 \mu \mathrm{M}$ & 10-22 нM & Lei et al. (2019) \\
\hline $\mathrm{Ti}_{3} \mathrm{C}_{2}-\mathrm{ATP}-\mathrm{Mn}_{3}\left(\mathrm{PO}_{4}\right)_{2} / \mathrm{GCE}$ & Superoxide anion & Amperometry & $0.5 \mathrm{nM}$ & $2.5 \mathrm{~nm}-14 \mu \mathrm{M}$ & Zheng et al. (2019) \\
\hline $\mathrm{Ti}_{3} \mathrm{C}_{2} \mathrm{Tx} / \mathrm{Pt} \mathrm{NP} / \mathrm{GCE}$ & ACOP, AA, UA, DA & DPV & $0.048 \mu \mathrm{M}$ & $0.25-2000 \mu \mathrm{M}$ & Lorencova et al. (2018, \\
\hline Nafion/ $\mathrm{Ti}_{3} \mathrm{C}_{2} \mathrm{~T} \times / \mathrm{GCE}$ & Bromate & DPV & $41 \mathrm{nM}$ & $50 \mathrm{~nm}-5 \mu \mathrm{M}$ & Rasheed et al. (2018) \\
\hline Alk- $\mathrm{Ti}_{3} \mathrm{C}_{2} / \mathrm{GCE}$ & $\begin{array}{l}\mathrm{Cd}(\mathrm{II}), \mathrm{Pb}(\mathrm{II}) \\
\mathrm{Cu}(\mathrm{II}), \mathrm{Hg}(\mathrm{II})\end{array}$ & SWASV & $0.098 \mu \mathrm{m}, 0.041 \mu \mathrm{m}$ & $0.1-1.5 \mu \mathrm{M}$ & Zhu et al. (2017) \\
\hline $\mathrm{Ti}_{3} \mathrm{C}_{2} \mathrm{~T}$ x-MXene & Carbendazim & DPV & $10.3 \mathrm{nM}$ & $50 \mathrm{nM}-100 \mu \mathrm{M}$ & Wu et al. (2019) \\
\hline TiN/GCE & UA, AA & DPV & 1.52 and $0.28 \mu \mathrm{M}$ & $\begin{array}{c}10-300 \mu \mathrm{M} \\
50-1500 \mu \mathrm{M}\end{array}$ & Liqin et al. (2017) \\
\hline $\begin{array}{l}\mathrm{Ni}_{3} \mathrm{NNS} / \mathrm{Ti} \\
\left(\mathrm{rGO} /\left(\mathrm{q}-\mathrm{C}_{3} \mathrm{~N}_{4}\right)(\mathrm{GCN})\right.\end{array}$ & $\begin{array}{l}\text { Glucose } \\
\mathrm{Cd}^{2+}\end{array}$ & $\begin{array}{l}\text { Amperometry } \\
\text { DPASV }\end{array}$ & $0.06 \mu \mathrm{M}$ & $0.2 \mu \mathrm{M}$ & Fengyu et al. (2018) \\
\hline
\end{tabular}

Malhotra et al. (2016a) have developed a non-invasive biosensor of serine $/ \mathrm{nZrO}_{2}$ to detect the oral cancer biomarker (CYFRA-21-1) that is highly efficient, with a sensitivity of $0.295 \mathrm{~mA} \mathrm{~mL} \mathrm{ng}^{-1}$. The same group of researchers, Malhotra et al. (2015) have continued with bovine serum albumin (BSA)/anti-CYFRA-21-1/3-aminopropyl triethoxy silane (APTES)/ZrO $/$ /ITO immunoelectrode for the detection of CYFRA-21-1 biomarker for oral cancer. An electrochemical immunosensor, BSA/anti-cTnI/APTES/nZrO2/ITO, was developed by an earlier research group Malhotra et al. (2017), for the identification of cardiac troponin I biomarker (acute myocardial infarction) detection, which exhibits a good sensitivity of $3.9 \mu \mathrm{A} \mathrm{ml} /(\mathrm{ng}$ $\mathrm{cm}^{2}$ ). Uzungolu (2018) worked on the development of $\mathrm{CeO}_{2}-\mathrm{ZrO}_{2}$ nanoparticle modified lactate oxidase enzyme, an enzymatic sensor in an oxygen-depleted environment. The fabrication of Au electrodes functionalized with $\mathrm{ZrO}_{2}$ thin film has been developed by Raileanu et al. (2018) for the determination of enzymatically produced thiocoline (Tch). Triglyceride tributyrin was detected using a bi-enzymatic biosensor of Chit-nano- $\mathrm{ZrO}_{2} / \mathrm{ITO}$ electrode and was developed by Solanki et al. (2016), with a good LOD of $155 \mu \mathrm{g} \mathrm{mL}{ }^{-1}$. A novel $\mathrm{Ga}_{2} \mathrm{O}_{3}$ / lignin and $\mathrm{ZrO}_{2} /$ lignin hybrid materials have been developed by Jędrzak et al. (2019) for the immobilization of glucose oxidase which acts as a biosensor for the detection of glucose. An amperometric choline biosensor was introduced by Ouiram et al. (2020) based on zirconium dioxide decorated gold nanoparticles $\left(\mathrm{ZrO}_{2} @ A u N P s\right)$, copper (I) oxide at manganese (IV) oxide $\left(\mathrm{Cu}_{2} \mathrm{O} @\right.$ $\left.\mathrm{MnO}_{2}\right)$, and immobilized choline oxidase $\left(\mathrm{ChO}_{\mathrm{x}}\right)$ onto a glassy carbon electrode (GCE) $\left(\mathrm{ChO}_{\mathrm{x}} / \mathrm{Cu}_{2} \mathrm{O} @ \mathrm{MnO}_{2}-\mathrm{ZrO}_{2} @ \mathrm{AuNP} / \mathrm{GCE}\right)$ for the detection of choline in blood samples.

\section{ZRO $_{2}$-CARBON BASED BIOSENSORS}

In the family of nanocarbon graphene oxide (GO), reduced graphene oxide ( $\mathrm{rGO}$ ), graphene, and carbon nanotubes are prominent new candidates in electrochemical sensors (Pumera, 2010). Graphene material has $\mathrm{sp}^{2}$ hybridized carbon atoms that possess a high electron transfer rate, surface area, good electrical conductivity, and act as a functional material to modify the bare electrode surfaces (Unwin et al., 2016). For the synthesis of graphene materials, different methods are proposed. However, each method has its advantages and limitations. Graphene oxide is a layered material where the oxygen content is high in the form 
of functional groups like hydroxyl, carboxyl, and epoxy groups for specific target molecules. On the reduction of graphene oxide through different methods, reduced graphene oxide (rGO) was obtained, which has good electrical conductivity and acts as a current enhancer in electrochemical sensors (Russo et al., 2011).

Devnani et al. (2017) synthesized $\mathrm{ZrO}_{2}$ /graphene/chitosan nanocomposite coupled with carbon paste electrode for the detection of dopamine in the presence of ascorbic acid and uric acid. A nanocomposite of zirconia with graphene for the detection of label-free exon-19 mutations has been developed by Lin et al. (2019). A novel $\mathrm{Au}-\mathrm{ZrO}_{2}$-graphene electrochemical sensor was fabricated by Tao et al. (2020) for the detection of methyl parathion. Earlier, Sun et al. (2015b) developed a nanocomposite of $\mathrm{ZrO}_{2}$ with graphene that was electrodeposited on the surface of a carbon ionic liquid electrode (CILE) to act as an electrochemical DNA sensor for the Staphylococcus aureus nuc gene sequence. In this succession, a novel biosensing electrode of $\mathrm{ZrO}_{2} / \mathrm{rGO}$ immobilized acetylcholinesterase (AChE) was developed by Mogha et al. (2016) for the detection of chlorpyrifos. Later, an efficient biosensing platform was designed by Malhotra et al. (2016b) using $\mathrm{ZrO}_{2} / \mathrm{rGO}$ for sensing the oral cancer biomarker (CYFRA-21-1). Chen et al. (2020) fabricated an electrochemical DNA sensor for the detection of nucleic acid using zirconia-reduced graphene oxide-thionine $\left(\mathrm{ZrO}_{2}\right.$-rGO-Thi) nanocomposite for integral DNA recognition. An anticancer drug (regorafenib, REG) was detected selectively along with other analytes of ascorbic acid and uric acid, using an electrochemical sensor made with $\mathrm{ZrO}_{2} / \mathrm{rGO}$ nanocomposite by a group of researchers (Venu et al., 2018), where it exhibits a good limit of detection $17 \mathrm{nM}$.

In another work, an immune sensor was fabricated using $\mathrm{ZrO}_{2} /$ rGO nanocomposite functionalized with L-Methionine as BSA/ antiOTA/Meth/ $\mathrm{ZrO}_{2}$-rGO/ITO was used for specific target detection of ochratoxin A (OTA) by (Gupta et al., 2017a). Puangjan et al. (2016) reported that $\mathrm{ZrO}_{2} / \mathrm{Co}_{3} \mathrm{O}_{4}$ reduced graphene oxide for the simultaneous detection of gallic acid (GA), caffeic acid (CA), and protocatechuic acid (PA). In other studies, reduced graphene oxide-zirconium dioxide-thionine (rGO$\mathrm{ZrO}_{2}$-Thi) nanocomposite was synthesized by (Chen et al., 2018) for electrochemical assay of protein kinase activity. The other carbon materials like amorphous carbon along with zirconia as an immunesensor for ochratoxin A (OTA) by (Solanki et al., 2016) and graphitic carbon nitride with zirconia, $\mathrm{ZrO}_{2} / \mathrm{g}-\mathrm{C}_{3} \mathrm{~N}_{4}$, nanocomposite were developed by Zarei (2020) as an aptasensor for the detection of tetracycline.

\section{$\mathrm{ZRO}_{2}$-METALS/MO-BASED BIOSENSORS}

A nanocomposite of $\mathrm{ZrO}_{2}$-ChCl-AuNPs/CPE was used to construct a carbon paste electrode as an electrochemical sensor by Shahamirifard et al. (2018) for simultaneous determination of gallic acid (GA) and uric acid (UA). Solanki et al. (2016) prepared aluminum-doped zirconium oxide nanoparticles for sensing ochratoxin A with a good limit of detection of $0.14 \mathrm{ng} \mathrm{ml}^{-1}$. For the detection of glucose in raw citrus aurantium var. Sinensis, a $\mathrm{ZrO}_{2}-\mathrm{Cu}$ (I) material was used by (Parashuram et al., 2019) and exhibits a very low limit of detection $0.25 \mathrm{mM}$ (Gu et al., 2016). conducted studies on a ternary and oxide $\mathrm{NiO}-\mathrm{TiO}_{2}-\mathrm{ZrO}_{2} / \mathrm{SO}_{4}{ }^{-2}$ which is a solid superacid catalyst for glucose oxidation. Furthermore, $\mathrm{ZrO}_{2} / \mathrm{ZnO}$ nanocomposites act as sensing material fabricated by (Wang et al., 2020) for the simultaneous detection of epinephrine (EA), uric acid (UA), and folic acid (FA) (Parthasarathy et al., 2019). introduced a method of detection of uric acid using Urs-GLDH/ $\mathrm{TiO}_{2}-\mathrm{ZrO}_{2} / \mathrm{ITO}$ electrode.

\section{METAL CARBIDE AND NITRIDE BASED BIOSENSORS}

Metal carbides and nitride usage has increased in recent years could potentially replace the conventional materials used in gas sensing, environmental remediation, photocatalysis, medicine, and ceramics. Moreover, a number of composites are made using transition metal carbide and nitrides especially the nanoform of various morphologies such as spheres, particles, plates, fibers, whiskers possessing significant properties including large surface area, high toughness, flexibility, low density, and thin walls with enhanced conductivity with good electrical properties (Donath et al., 2002; Cheng et al., 2006; Guo et al., 2008; Zhao et al., 2008; Karan et al., 2009; Li et al., 2009; Ni et al., 2009; Yu et al., 2009), which are summarized in Table 3. These materials are quite promising in making electrochemical sensors.

Titanium based carbides $\left(\mathrm{Ti}_{3} \mathrm{C}_{2}\right)$ with graphene oxide based electrochemical sensors were synthesized and used as effective sensors for $\mathrm{H}_{2} \mathrm{O}_{2}$ as reported by (Zheng et al., 2018). Lei et al. reported wearable and stretchable biosensors for the quantification of biomarkers like glucose and lactose in sweat and efficiently act as monitors for non-invasive biomarkers (Lei et al., 2019). Mxene based nanocomposite based biomimmetic enzyme was used for the quantification of superoxide anion, which is considered to be a significant biomarker in the diagnosis of cancer by Zheng et al. (2019). In addition, $\mathrm{Ti}_{3} \mathrm{C}_{2}$ TxePtNP composite derived from the $\mathrm{Pt}$ precursor by reduction process on Mxene surface are used as an effective electrochemical sensor for various biomolecules (Lorencova et al., 2018).

Nafion based titanium carbides are used for the detection of bromate in water resources (Rasheed et al., 2018). The detection of heavy metals such as $\mathrm{Cd}$ (II), $\mathrm{Pb}$ (II), Cu (II), and $\mathrm{Hg}$ (II) at trace level is essential due to the detrimental effects they have on humans and the environment. (Zhu et al., 2017). Delaminated $\mathrm{Ti}_{3} \mathrm{C}_{2}$ TxeMXene was used as an electrode modifier for the detection of fungicide carbendazim (Wu et al., 2019). Titanium nitrite based electrochemical sensors were used for the detection of ascorbic acid and uric acid (Liqin et al., 2017). Metallic nickel nanosheets are efficiently used for selective selection of glucose molecule as a non enzymatic sensor (Fengyu et al., 2018). Wang et al. reported carbon nitide based graphene incorporated carbon nanocomposites as selective sensors for detecting cadmium ions (Wang et al., 2018).

\section{CONCLUSION}

The present study has reviewed the electrochemical biosensor applications of advanced ceramics, particularly metal and 
metal oxide-based ceramics. The study discussed the working mechanisms and methods used to modify the base electrode with these advanced ceramics. $\mathrm{ZnO} / \mathrm{Al}_{2} \mathrm{O}_{3}$ / $\mathrm{Cr}_{2} \mathrm{O}_{3}$ were found to show the lowest detection limit of $82.25 \mathrm{pM}$ with a sensitivity of $2.09 \times 10^{2} \mu \mathrm{A} \mu \mathrm{M}-{ }^{1} \mathrm{~cm}^{-2}$ compared to all other ceramic based electrochemical biosensors. Similarly, among, metal carbides and nitrides, $\mathrm{Ti}_{3} \mathrm{C}_{2}$-ATP- $\mathrm{Mn}_{3}\left(\mathrm{PO}_{4}\right)_{2} / \mathrm{GCE}$ was found to show the lowest detection limit of $0.5 \mathrm{~nm}$. Table 4 gives a detailed summary

\section{REFERENCES}

Alam, M. M., Asiri, A. M., Uddin, M. T., Islam, M. A., and Rahman, M. M. (2018a). In-situ Glycine Sensor Development Based ZnO/Al2 O3/Cr2 O3 Nanoparticles. ChemistrySelect 3, 11460-11468. doi:10.1002/slct.201802750

Alam, M. M., Asiri, A. M., Uddin, M. T., Islam, M. A., and Rahman, M. M. (2018b). Wet-chemically Prepared Low-Dimensional ZnO/Al2O3/Cr2O3 Nanoparticles for Xanthine Sensor Development Using an Electrochemical Method. RSC Adv. 8, 12562-12572. doi:10.1039/c8ra01734d

Alam, M. M., Rahman, M. M., Uddin, M. T., Asiri, A. M., Inamuddin, M. T. S. C., Saeed Chani, M. T., et al. (2020). Development of L-Glutamic Acid Biosensor with Ternary $\mathrm{ZnO} / \mathrm{NiO} / \mathrm{Al} 2 \mathrm{O} 3$ Nanoparticles. J. Lumin. 227, 117528. doi:10. 1016/j.jlumin.2020.117528

Bojarski, Z., Wokulska, K., and Wokulski, Z. (1981). Growth and Morphology of Titanium Nitride Whiskers. J. Cryst. Growth 52, 290-295. doi:10.1016/00220248(81)90207-4

Chen, Z., Liu, X., Liu, D., Li, F., Wang, L., and Liu, S. (2020). Ultrasensitive Electrochemical DNA Biosensor Fabrication by Coupling an Integral Multifunctional Zirconia-Reduced Graphene Oxide-Thionine Nanocomposite and Exonuclease I-Assisted Cleavage. Front. Chem. 8, 1-11. doi:10.3389/fchem.2020.00521

Chen, Z., Liu, Y., Hao, L., Zhu, Z., Li, F., and Liu, S. (2018). Reduced Graphene Oxide-Zirconium Dioxide-Thionine Nanocomposite Integrating Recognition, Amplification, and Signaling for an Electrochemical Assay of Protein Kinase Activity and Inhibitor Screening. ACS Appl. Bio Mater. 1, 1557-1565. doi:10. 1021/acsabm.8b00451

Cheng, D., Xia, H., and Chan, H. S. O. (2006). Fabrication of Polymeric Hollow Nanospheres, Hollow Nanocubes and Hollow Plates. Nanotechnology 17, 1661-1667. doi:10.1088/0957-4484/17/6/021

Devnani, H., Ansari, S., Satsangee, S. P., and Jain, R. (2017). ZrO 2 -GrapheneChitosan Nanocomposite Modified Carbon Paste Sensor for Sensitive and Selective Determination of Dopamine. Mater. Today Chem. 4, 17-25. doi:10. 1016/j.mtchem.2017.02.004

Donath, E., Moya, S., Neu, B., Sukhorukov, G. B., Georgieva, R., Voigt, A., et al. (2002). Hollow Polymer Shells from Biological Templates: Fabrication and Potential Applications. Chem. Eur. J. 8, 5481-5485. doi:10.1002/15213765(20021202)8:23\%3C5481::AID-CHEM5481\%3E3.0.CO;2-8

Fengyu, X., Tingting, L., Lisi, X., Xuping, S., and Yonglan, L. (2018). Metallic Nickel Nitride Nanosheet: An Efficient Catalyst Electrode for Sensitive and Selective Non-enzymatic Glucose Sensing. Sensors Actuators B: Chem. 255, 2794-2799. doi:10.1016/j.snb.2017.09.095

Ganjali, M. R., Fariba, G. N., Hadi, B., Shohreh, J., Morteza, R., and Bagher, L. (2017a). Highly Sensitive Voltammetric Sensor for Determination of Ascorbic Acid Using Graphite Screen Printed Electrode Modified with $\mathrm{ZnO} / \mathrm{Al}_{2} \mathrm{O}_{3}$ Nanocomposite. Int. J. Electrochem. Sci. 12, 3231-3240. doi:10.20964/2017. 04.07

Ganjali, M. R., Fariba, G. N., Somayeh, T., Hadi, B., Eslam, P., and Bagher, L. (2017b). Determination of Salicylic Acid by Differential Pulse Voltammetry Using $\mathrm{ZnO} / \mathrm{Al} 2 \mathrm{O} 3$ Nanocomposite Modified Graphite Screen Printed Electrode. Int. J. Electrochem. Sci. 12, 9972-9982. doi:10.20964/2017.11.49

Ganjali, M. R., Hadi, B., Reza, Z., Somayeh, T., Morteza, R., and Bagher, L. (2018). Voltammetric Determination of Dopamine Using Glassy Carbon Electrode Modified with $\mathrm{ZnO} / \mathrm{Al} 2 \mathrm{O} 3$ Nanocomposite. Int. J. Electrochem. Sci. 13, 2519-2529. doi:10.20964/2018.03.11 of of the electrochemical bio-sensing properties of metal carbide and nitrides.

\section{AUTHOR CONTRIBUTIONS}

All authors listed have made a substantial, direct, and intellectual contribution to the work and approved it for publication.

Giarola, J. D. F., Borges, K. B., Tarley, C. R. T., de Oliveira, F. M., Ribeiro, E. S., and Pereira, A. C. (2017). Development and Application of Graphite-SiO 2/Al 2 O 3/Nb 2 O 5 -methylene Blue (GRP-SiAlNb-MB) Composite for Electrochemical Determination of Dopamine. Arabian J. Chem. 10, 430-438. doi:10.1016/j. arabjc.2015.03.006

Górska, A., Paczosa-Bator, B., Wyrwa, J., and Piech, R. (2020). New Electrochemical Sensor of Prolonged Application for Metformin Determination Based on Hydrated Ruthenium Dioxide-Carbon BlackNafion Modified Glassy Carbon Electrode. Electroanalysis 32, 1875-1884. doi:10.1002/elan.202060012

Gu, Y., Yang, H., Li, B., Mao, J., and An, Y. (2016). A Ternary Nanooxide NiO-TiO2$\mathrm{ZrO} 2 / \mathrm{SO} 42-$ as Efficient Solid Superacid Catalysts for Electro-Oxidation of Glucose. Electrochimica Acta 194, 367-376. doi:10.1016/j.electacta.2016.02.113

Guo, Z., Liu, J., Jia, Y., Chen, X., Meng, F., Li, M., et al. (2008). Template Synthesis, Organic Gas-Sensing and Optical Properties of Hollow and Porous In2O3 nanospheres. Nanotechnology 19, 345704. doi:10.1088/0957-4484/19/34/ 345704

Gupta, P. K., Pachauri, N., Khan, Z. H., and Solanki, P. R. (2017a). One Pot Synthesized Zirconia Nanoparticles Embedded in Amino Functionalized Amorphous Carbon for Electrochemical Immunosensor. J. Electroanalytical Chem. 807, 59-69. doi:10.1016/j.jelechem.2017.11.018

Hernandez-Vargas, G., Sosa-Hernández, J., Saldarriaga-Hernandez, S., Villalba-Rodríguez, A., Parra-Saldivar, R., and Iqbal, H. (2018). Electrochemical Biosensors: A Solution to Pollution Detection with Reference to Environmental Contaminants. Biosensors 8, 29-21. doi:10. 3390/bios8020029

Hoch, L. B., Mack, E. J., Hydutsky, B. W., Hershman, J. M., Skluzacek, J. M., and Mallouk, T. E. (2008). Carbothermal Synthesis of Carbon-Supported Nanoscale Zero-Valent Iron Particles for the Remediation of Hexavalent Chromium. Environ. Sci. Technol. 42, 2600-2605. doi:10.1021/es702589u

Huo, J., Song, H., Chen, X., and Lian, W. (2006). Formation and Transformation of Carbon-Encapsulated Iron Carbide/iron Nanorods. Carbon 44, 2849-2852. Available at: http://pascal-francis.inist.fr/vibad/index.php? action=getRecordDetail\&idt=18119793. doi:10.1016/j.carbon.2006.06.016

Huo, K., Hu, Y., Ma, Y., Lü, Y., Hu, Z., and Chen, Y. (2007). Synthesis and Field Emission Properties of Titanium Carbide Nanowires. Nanotechnology 18, 145615. doi:10.1088/0957-4484/18/14/145615

Jędrzak, A., Tomasz, R., Maria, K., Agnieszka, K-R., Jakub, Z., Adam, P., et al. (2019). Advanced Ga2 O3/Lignin and Zro2/Lignin Hybrid Microplatforms for Glucose Oxidase Immobilization: Evaluation of Biosensing Properties by Catalytic Glucose Oxidation. Catalysts 9, 1044. doi:10.3390/ catal9121044

Johnsson, M. (2000). Synthesis and Characterization of NbC Whiskers. J. Mater. Sci. Lett. 19, 1571-1574. doi:10.1023/A:1006785324911

Johnsson, M. (2004). Synthesis of Boride, Carbide, and Carbonitride Whiskers. Solid State Ionics 172, 365-368. doi:10.1016/j.ssi.2004.01.045

Joseph, R. S., William, R. P., and Sheng, Y. (2003). Sensors, Chemical Sensors, Electrochemical Sensors, and ECS. J. Electrochem. Soc. 150, S11. doi:10.1149/1. 1539051

Karan, N. S., Agrawal, A., Pandey, P. K., Smitha, P., Sharma, S. J., Mishra, D. P., et al. (2009). Diffusion Flame Synthesis of Hollow, Anatase TiO2 Nanoparticles. Mater. Sci. Eng. B 163, 128-133. doi:10.1016/j.mseb.2009.05.005

Kato, A., and Tamari, N. (1980). Some Common Aspects of the Growth of TiN, ZrN, TiC and ZrC Whiskers in Chemical Vapor Deposition. J. Cryst. Growth 49, 199-203. doi:10.1016/0022-0248(80)90083-4 
Kim, I-S., and Kumta, P. N. (2003). Hydrazide Sol-Gel Synthesis of Nanostructured Titanium Nitride: Precursor Chemistry and Phase Evolution. J. Mater. Chem. 13, 2028-2035. doi:10.1039/b301964k

Krishnarao, R. V., Subrahmanyam, J., and Ramakrishna, V. (2001). Synthesis of TiC Whiskers through Carbothermal Reduction of $\mathrm{TiO}_{2}$. J. Mater. Synth. Process. 9, 1-10. doi:10.1023/A:1011345529418

Lei, Y., Zhao, W., Zhang, Y., Jiang, Q., He, J. H., Baeumner, A. J., et al. (2019). A MXene-Based Wearable Biosensor System for High-Performance In Vitro Perspiration Analysis. Small 15, 1901190. doi:10.1002/smll.201901190

Li, Y., Chen, J., Niu, A., Xue, F., Cao, Y., and Xu, Q. (2009). Preparation of Hollow Poly (Styrene-co-divinylbenzene) Particles with Variable Cavity Sizes and Further Fabrication of Hollow TiO2 Particles Using Solid Poly (Styrene-codivinylbenzene) Particles as Templates. Colloids Surf. A: Physicochemical Eng. Aspects 342, 107-114. doi:10.1016/j.colsurfa.2009.04.021

Lin, L. P., Tan, M. T. T., and Loh, H. S. (2019). "Electrochemical DNA Sensor Based on Graphene/Zirconia Nanocomposite for Label-free Detection of Exon-19 Mutations in Lung Cancer," in ACM International Conference Proceeding Series, Tokyo, Japan, 223-228. doi:10.1145/3326172.3326176

Liqin, Z., Jiao, F., Kuo-Chih, C., Lei, S., and Xinmei, H. (2017). Simultaneously Electrochemical Detection of Uric Acid and Ascorbic Acid Using Glassy Carbon Electrode Modified with Chrysanthemum-like Titanium Nitride. J. Electroanalytical Chem. 803, 11-18. doi:10.1016/j.jelechem.2017.09.006

Lorencova, L., Bertok, T., Filip, J., Jerigova, M., Velic, D., Kasak, P., et al. (2018). Highly Stable Ti3C2Tx (MXene)/Pt Nanoparticles-Modified Glassy Carbon Electrode for $\mathrm{H} 2 \mathrm{O} 2$ and Small Molecules Sensing Applications. Sensors Actuators B: Chem. 263, 360-368. doi:10.1016/j.snb.2018.02.124

Malhotra, B. D., Augustine, S., and Kumar, S. (2017). Protein Functionalized Nanostructured Zirconia Based Electrochemical Immunosensor for Cardiac Troponin I Detection. J. Mater. Res. 32, 2966-2972. doi:10.1557/jmr.2017.102

Malhotra, B. D., Kumar, S., Tiwari, S., Srivastava, S., Srivastava, M., Yadav, B. K., et al. (2015). Biofunctionalized Nanostructured Zirconia for Biomedical Application: A Smart Approach for Oral Cancer Detection. Adv. Sci. 2, 1500048. doi:10.1002/advs.201500048

Malhotra, B. D., Sharma, J. G., Maji, S., and Kumar, S. (2016a). A Biocompatible Serine Functionalized Nanostructured Zirconia Based Biosensing Platform for Noninvasive Oral Cancer Detection. RSC Adv. 6, 77037-77046. doi:10.1039/c6ra07392a

Malhotra, B. D., Sharma, J. G., Maji, S., and Kumar, S. (2016b). Nanostructured Zirconia Decorated Reduced Graphene Oxide Based Efficient Biosensing Platform for Non-invasive Oral Cancer Detection. Biosens. Bioelectron. 78, 497-504. doi:10.1016/j.bios.2015.11.084

Malikova, N., Ali-zadeh, N., and Tofik, N. (2015). Catalase-Biomimetic Sensor on Base of Electrochemical Electrode TPhPFe(III)/Al2O3/Pb and TPhPFe(III)/ Al2O3/Si. J. Chem. Chem. Eng. 9, 3-7. doi:10.17265/1934-7375/2015.01.010

Mekawy, M. M., Hassan, R. Y. A., Ramnani, P., Yu, X., and Mulchandani, A. (2018). Electrochemical Detection of Dihydronicotinamide Adenine Dinucleotide Using Al2O3-GO Nanocomposite Modified Electrode. Arabian J. Chem. 11 (6), 942-949. doi:10.1016/j.arabjc.2018.03.017

Miao, J., Li, X., Li, Y., Dong, X., Zhao, G., Fang, J., et al. (2019). Dual-signal sandwich Electrochemical Immunosensor for Amyloid $\beta$-protein Detection Based on Cu-Al2O3-G-C3n4-Pd and UiO-66@PANI-MB. Analytica Chim. Acta 1089, 48-55. doi:10.1016/j.aca.2019.09.017

Mogha, N. K., Sahu, V., Sharma, M., Sharma, R. K., and Masram, D. T. (2016). Biocompatible ZrO2- Reduced Graphene Oxide Immobilized AChE Biosensor for Chlorpyrifos Detection. Mater. Des. 111, 312-320. doi:10.1016/j.matdes. 2016.09.019

Ni, S., Lin, S., Pan, Q., Yang, F., Huang, K., Wang, X., et al. (2009). Synthesis of Core-Shell $a-\mathrm{Fe} 2 \mathrm{O} 3$ Hollow Micro-spheres by a Simple Two-step Process. J. Alloys Comp. 478, 876-879. doi:10.1016/j.jallcom.2008.12.038

Ouiram, T., Moonla, C., Preechaworapun, A., Muangpil, S., Maneeprakorn, W., and Tangkuaram, T. (2020). Choline Oxidase Based Composite ZrO $2 @$ @uNPs with Cu 2 O@MnO 2 Platform for Signal Enhancing the Choline Biosensors. Electroanalysis 33, 455-463. doi:10.1002/elan.202060340

Parashuram, L., Sreenivasa, S., Akshatha, S., Udayakumar, V., and Sandeep kumar, S. (2019). A Non-enzymatic Electrochemical Sensor Based on $\mathrm{ZrO} 2: \mathrm{Cu}(\mathrm{I})$ Nanosphere Modified Carbon Paste Electrode for Electro-Catalytic Oxidative Detection of Glucose in Raw Citrus Aurantium Var. Sinensis. Food Chem. 300, 125178. doi:10.1016/j.foodchem.2019.125178
Parthasarathy, P., Vivekanandan, S., and Basha A., A. (2019). "Structural, Optical and Electrochemical Response Studies of TiO2-ZrO2 Nanocomposite for Uric Acid Detection," in Innovations in Power and Advanced Computing Technologies(i-PACT), Vellore, India, 1-6. doi:10.1109/i-PACT44901.2019. 8960032

Parvin, M. H., Arjomandi, J., and Lee, J. Y. (2018). $\gamma$-Al2O3 Nanoparticle Catalyst Mediated Polyaniline Gold Electrode Biosensor for Vitamin E. Catal. Commun. 110, 59-63. doi:10.1016/j.catcom.2018.03.009

Pohanka, M., and Skládal, P. (2008). Electrochemical Biosensors - Principles and Applications. Jab 6, 57-64. doi:10.32725/jab.2008.008

Puangjan, A., and Chaiyasith, S. (2016). An Efficient $\mathrm{ZrO} 2 / \mathrm{Co} 3 \mathrm{O} 4 /$ reduced Graphene Oxide Nanocomposite Electrochemical Sensor for Simultaneous Determination of Gallic Acid, Caffeic Acid and Protocatechuic Acid Natural Antioxidants. Electrochimica Acta 211, 273-288. doi:10.1016/j.electacta.2016. 04.185

Pumera, M. (2010). Graphene-Based Nanomaterials and Their Electrochemistry. Chem. Soc. Rev. 39, 4146-4157. doi:10.1039/c002690p

Raileanu, A., Piazzoni, C., Borghi, F., Bettini, L. G., Shacham-Diamand, Y., Santaniello, T., et al. (2018). An Amperometric Sensor for Thiocholine Based on Cluster-Assembled Zirconia Modified Electrodes. j nanosci nanotechnol 18, 6905-6912. doi:10.1166/jnn.2018.15518

Rakib, R. H., Hasnat, M. A., Uddin, M. N., Alam, M. M., Asiri, A. M., Rahman, M. M., et al. (2019). Fabrication of a 3,4-Diaminotoluene Sensor Based on a TiO 2 Al 2 O 3 Nanocomposite Synthesized by a Fast and Facile Microwave Irradiation Method. ChemistrySelect 4, 12592-12600. doi:10.1002/slct. 201902394

Rasheed, P. A., Pandey, R. P., Rasool, K., and Mahmoud, K. A. (2018). Ultrasensitive Electrocatalytic Detection of Bromate in Drinking Water Based on Nafion/Ti3C2Tx (MXene) Modified Glassy Carbon Electrode. Sensors Actuators B: Chem. 265, 652-659. doi:10.1016/j.snb.2018.03.103

Ruano, P. (2016). Intech Open, the World 'S Leading Publisher of Open Access Books Built by Scientists. Available at: https://www.intechopen.com/books/ advanced-biometric-technologies/liveness-detection-in-biometrics (Accessed January 1, 2021).13

Russo, S. M. F., Koshino, M., Yamamoto, M., and Taruch, S. (2011). Electronic Transport Properties of Few-Layer Graphene Materials. in Graphene Synthesis, Characterization, Properties and Applications (Norderstedt, Germany: BOD-Books on Demand). doi:10.5772/22530

Sagadevan, S., Podder, J., and Das, I. (2016). Hydrothermal Synthesis of Zirconium Oxide Nanoparticles and its Characterization. J. Mater. Sci. Mater. Electron. 27, 5622-5627. doi:10.1007/s10854-016-4469-6

Sajitha, E. P., Prasad, V., Subramanyam, S. V., Kumar Mishra, A., Sarkar, S., and Bansal, C. (2007). Structural, Magnetic and Mössbauer Studies of Iron Inclusions in a Carbon Matrix. J. Magnetism Magn. Mater. 313, 329-336. doi:10.1016/j.jmmm.2007.02.001

Schnepp, Z., Wimbush, S. C., Antonietti, M., and Giordano, C. (2010). Synthesis of Highly Magnetic Iron Carbide Nanoparticles via a Biopolymer Route. Chem. Mater. 22, 5340-5344. doi:10.1021/cm101746z

Shahamirifard, S. A., Ghaedi, M., Razmi, Z., and Hajati, S. (2018). A Simple Ultrasensitive Electrochemical Sensor for Simultaneous Determination of Gallic Acid and Uric Acid in Human Urine and Fruit Juices Based on Zirconia-Choline Chloride-Gold Nanoparticles-Modified Carbon Paste Electrode. Biosens. Bioelectron. 114, 30-36. doi:10.1016/j.bios.2018.05.009

Sivasankar, K., Devasenathipathy, R., Wang, S.-F., Kohila rani, K., Raja, D. S., and Lin, C.-H. (2018). Synthesis of Hierarchical Mesoporous Graphite oxide/Al $2 \mathrm{O}$ 3 from MIL-100(Al) for the Electrochemical Determination of Caffeic Acid in Red Wine Samples. J. Taiwan Inst. Chem. Eng. 84, 188-195. doi:10.1016/j.jtice. 2018.01.006

Solanki, S., Pandey, C. M., Soni, A., Sumana, G., and Biradar, A. M. (2016). An Amperometric Bienzymatic Biosensor for the Triglyceride Tributyrin Using an Indium Tin Oxide Electrode Coated with Electrophoretically Deposited Chitosan-Wrapped Nanozirconia. Microchim Acta 183, 167-176. doi:10. 1007/s00604-015-1618-1

Sun, J.-y., Gan, T., Deng, Y.-p., Shi, Z.-x., and Lv, Z. (2015a). Pt NanoparticlesFunctionalized Hierarchically Porous $\gamma$-Al2O3 Hollow Spheres Based Electrochemical Sensor for Ultrasensitive Guaiacol Detection. Sensors Actuators B: Chem. 211, 339-345. doi:10.1016/j.snb.2015.01.104 
Sun, W., Wang, X., Wang, W., Lu, Y., Xi, J., Zheng, W., et al. (2015b). Electrochemical DNA Sensor for Staphylococcus Aureus Nuc Gene Sequence with Zirconia and Graphene Modified Electrode. J. Solid State. Electrochem. 19, 2431-2438. doi:10.1007/s10008-015-2893-9

Tao, T., Zhou, Y., He, C., He, H., Ma, M., Cai, Z., et al. (2020). Highly Sensitive Methyl Parathion Sensor Based on Au-ZrO2 Nanocomposites Modified Graphene Electrochemical Transistor. Electrochimica Acta 357, 136836. doi:10.1016/j.electacta.2020.136836

Unwin, P. R., Güell, A. G., and Zhang, G. (2016). Nanoscale Electrochemistry of Sp2 Carbon Materials: From Graphite and Graphene to Carbon Nanotubes. Acc. Chem. Res. 49, 2041-2048. doi:10.1021/acs.accounts.6b00301

Uzunoglu, A. (2018). CeO2-ZrO2Nanoparticle-Modified Enzymatic Lactate Biosensors with Reduced Oxygen Susceptibility. J. Electrochem. Soc. 165, B436-B441. doi:10.1149/2.0601810jes

Veloso, A. J., Cheng, X. R., and Kerman, K. (2012). 1-Electrochemical Biosensors for Medical Applications. New Delhi, India: Woodhead Publishing Series in Biomaterials, 3-40. doi:10.1533/9780857097187.1.3

Venu, M., Venkateswarlu, S., Reddy, Y. V. M., Seshadri Reddy, A., Gupta, V. K., Yoon, M., et al. (2018). Highly Sensitive Electrochemical Sensor for Anticancer Drug by a Zirconia Nanoparticle-Decorated Reduced Graphene Oxide Nanocomposite. ACS Omega 3, 14597-14605. doi:10.1021/acsomega.8b02129

Vinay, S. B., Supriya, S., and Gurumurthy, H. (2020). Review-Biomass Derived Carbon Materials for Electrochemical Sensors. J. Electrochem. Soc. 167, 037526. doi:10.1149/2.0262003jes

Wang, J. N., Zhang, L., Yu, F., and Sheng, Z. M. (2007). Synthesis of Carbon Encapsulated Magnetic Nanoparticles with Giant Coercivity by a spray Pyrolysis Approach. J. Phys. Chem. B 111, 2119-2124. doi:10.1021/ jp0674118

Wang, Q., Si, H., Zhang, L., Li, L., Wang, X., and Wang, S. (2020). A Fast and Facile Electrochemical Method for the Simultaneous Detection of Epinephrine, Uric Acid and Folic Acid Based on $\mathrm{ZrO} 2 / \mathrm{ZnO}$ Nanocomposites as Sensing Material. Analytica Chim. Acta 1104, 69-77. doi:10.1016/j.aca.2020.01.012

Wang, Y., Ying, X., Hui, T., Shi, W., Qianying, Z., Mingjing, Z., et al. (2018). Application of Sensitive Sensor Modified with MWNTs/Al2O3/poly-L-Lysine Composite for $17 \beta$-estradiol Determination in Pregnant Woman Blood. Int. J. Electrochem. Sci. 13, 147-158. doi:10.20964/2018.01.20

Weimer, A. W., Nilsen, K. J., Cochran, G. A., and Roach, R. P. (1993). Kinetics of Carbothermal Reduction Synthesis of Beta Silicon Carbide. Aiche J. 39, 493-503. doi:10.1002/aic.690390311

Wokulski, Z. (1987). The Influence of Nickel on VLS Growth and Real Structure of TiC Whiskers. J. Cryst. Growth 82, 427-434. doi:10.1016/0022-0248(87) 90334-4
Worsfold, P. J. (1995). Classification and Chemical Characteristics of Immobilized Enzymes (Technical Report). Pure Appl. Chem. 67, 597-600. doi:10.1351/ pac199567040597

Wu, D., Wu, M., Yang, J., Zhang, H., Xie, K., Lin, C.-T., et al. (2019). Delaminated Ti3C2Tx (MXene) for Electrochemical Carbendazim Sensing. Mater. Lett. 236, 412-415. doi:10.1016/j.matlet.2018.10.150

Wu, W., Caiyan, L., Fang, H., Huaying, L., Yuting, W., Ding, H., et al. (2018). A Simple and Novel Electroanalytical Method for Determination of Brain Serotonin Based on the MWNTs/Al2O3/chitosan SPE. Int. J. Electrochem. Sci. 13, 7129-7140. doi:10.20964/2018.07.69

Yu, L.-Y., Xu, Z.-L., Shen, H.-M., and Yang, H. (2009). Preparation and Characterization of PVDF-SiO2 Composite Hollow Fiber UF Membrane by Sol-Gel Method. J. Membr. Sci. 337, 257-265. doi:10.1016/j.memsci.2009. 03.054

Zarei, M. (2020). Sensitive Visible Light-Driven Photoelectrochemical Aptasensor for Detection of Tetracycline Using ZrO2/g-C3n4 Nanocomposite. Sensors Int. 1, 100029. doi:10.1016/j.sintl.2020.100029

Zhao, H., Li, Y., Liu, R., Zhao, F., and Hu, Y. (2008). Synthesis Method for Silica Needle-Shaped Nano-Hollow Structure. Mater. Lett. 62, 3401-3403. doi:10. 1016/j.matlet.2008.03.020

Zheng, J., Diao, J., Jin, Y., Ding, A., Wang, B., Wu, L., et al. (2018). An Inkjet Printed Ti3C2-GO Electrode for the Electrochemical Sensing of Hydrogen Peroxide. J. Electrochem. Soc. 165 (5), B227-B231. doi:10.1149/2.0051807jes

Zheng, J., Wang, B., Jin, Y., Weng, B., and Chen, J. (2019). Nanostructured MXene-Based Biomimetic Enzymes for Amperometric Detection of Superoxide Anions from HepG2 Cells. Microchim Acta 186, 95. doi:10. 1007/s00604-018-3220-9

Zhu, X., Liu, B., Hou, H., Huang, Z., Zeinu, K. M., Huang, L., et al. (2017). Alkaline Intercalation of Ti3C2 MXene for Simultaneous Electrochemical Detection of $\mathrm{Cd}(\mathrm{II}), \mathrm{Pb}(\mathrm{II}), \mathrm{Cu}(\mathrm{II})$ and $\mathrm{Hg}(\mathrm{II})$. Electrochimica Acta 248, 46-57. doi:10.1016/j. electacta.2017.07.084

Conflict of Interest: The authors declare that the research was conducted in the absence of any commercial or financial relationships that could be construed as a potential conflict of interest.

Copyright (c) 2021 Subbaiah, Ratnam, Janardhan, Shiprath, Manjunatha, Ramesha, Prasad, Ramesh and Babu. This is an open-access article distributed under the terms of the Creative Commons Attribution License (CC BY). The use, distribution or reproduction in other forums is permitted, provided the original author(s) and the copyright owner(s) are credited and that the original publication in this journal is cited, in accordance with accepted academic practice. No use, distribution or reproduction is permitted which does not comply with these terms. 